\title{
New records of phorid flies (Diptera, Phoridae) from Rio Grande do Sul, with five new records to Brazil
}

\author{
Juliano L.P. Duarte, ${ }^{1,2}$ Dayana B. Vaz, ${ }^{2}$ Rodrigo F. Krüger ${ }^{1,2}$
}

1 Universidade Federal de Pelotas (UFPel), Instituto de Biologia, Departamento de Microbiologia e Parasitologia, Programa de Pós-Graduação em Parasitologia, Campus Universitário Capão do Leão, s/nº Caixa postal 354, 96010-900, Pelotas, RS, Brazil. 2 Universidade Federal de Pelotas (UFPel), Instituto de Biologia, Departamento de Microbiologia e Parasitologia, Laboratório de Ecologia de Parasitos e Vetores, Campus Universitário Capão do Leão, s/nº, Caixa postal 354, 96010-900, Pelotas, RS, Brazil.

Corresponding author: Juliano L.P. Duarte, duartejlp@gmail.com

\begin{abstract}
This compilation is the result of identification of material recently collected from Southern Brazil. Forty-one new records of Phoridae are recorded for the state of Rio Grande do Sul, and the species Eibsfeldtphora cumsaltensis Disney 2009, Megaselia (M.) gracilipalpis Borgmeier 1969, Megaselia (Aphiochaeta) latimanus (Malloch, 1914), Melaloncha curvata Brown, 2005, and Trophodeinus vicinus (Borgmeier, 1963) are recorded for the first time in Brazil. Species are distributed in 18 genera and 3 subfamilies. The total known diversity of phorids in the state is augmented from 10 to 51 species. An updated distribution for Brazil is presented for each species.
\end{abstract}

\section{Key words}

Diversity; distribution; Neotropical region; Pampa biome; Scuttle flies.

\section{Introduction}

Phoridae is a family of small or very minute flies, which is among the richest families of Diptera. Estimated total diversity of the family ranges from 25 to 50 thousand species (Disney 1983, Gaston 1991); however, only about 4000 species are currently known to science (Ament and Brown 2016). A large part of these undescribed species is believed to be from the Neotropical Region, which remains in general largely undersampled.

The distributions of phorid species are also considerably unknown, with many species known only from their type locality.

Most of the knowledge on phorid distribution in Brazil is based on the studies of Father Thomas Borg- meier who published over a hundred articles describing more than a thousand species of phorids (Kempf 1972). Unfortunately, the material Borgmeier used in his studies is mostly from the states of Santa Catarina and Rio de Janeiro, what causes a bias in the knowledge on the species distribution.

According to Ament and Pereira (2017) there are currently 851 species of Phoridae known for the country, although estimates suggest a diversity of up to 5,000 species (Carvalho et al. 2012).

Surveys of Brachycera dipterans fauna are scarce in Rio Grande do Sul state. The diversity of the order in this state is mostly known from few families, such as Calliphoridae (Vianna et al. 1998, Azevedo et al. 2013), 


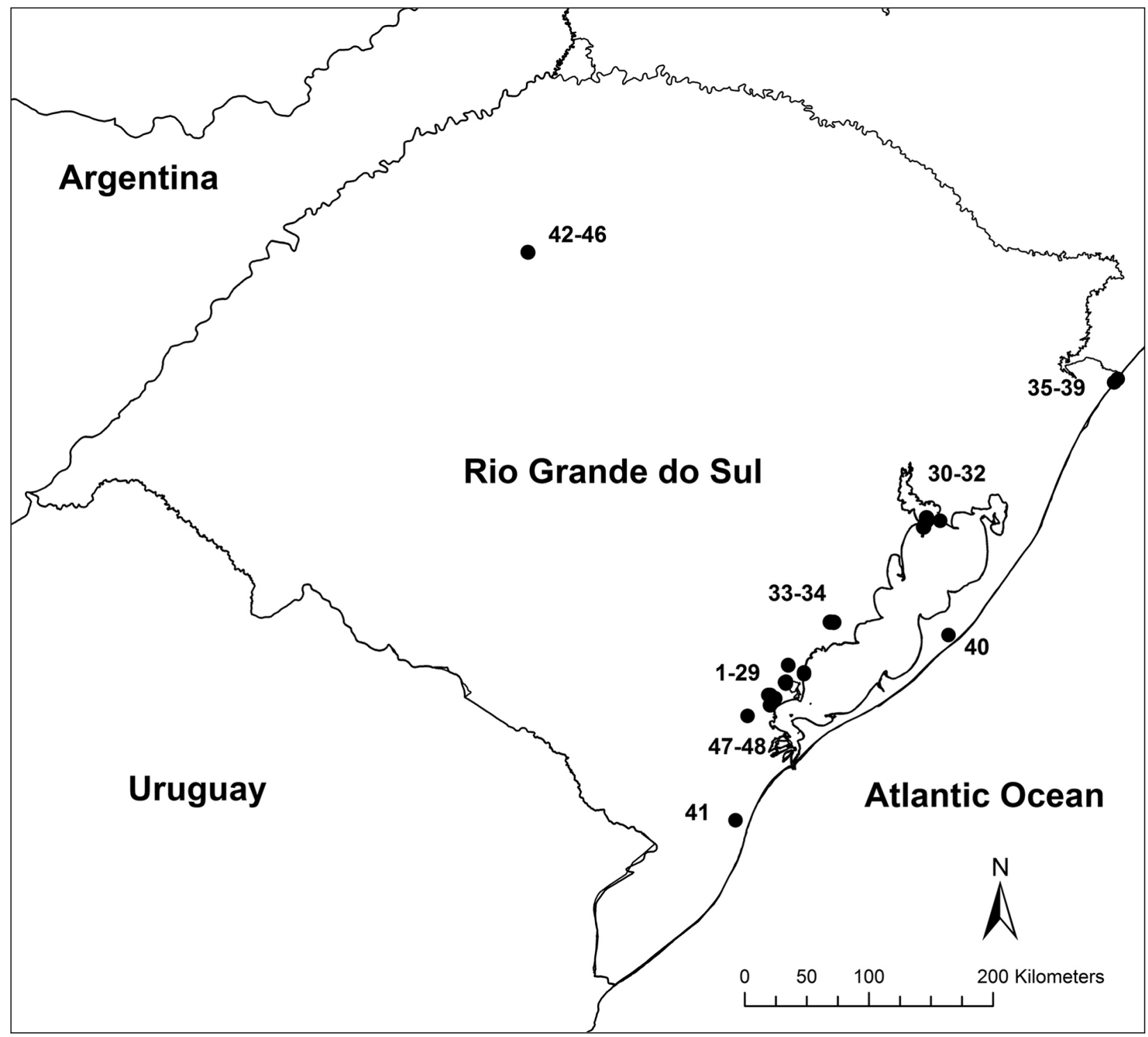

Figure 1. Map of Rio Grande do Sul state, Brazil showing the collect localities of the material used in this study.

Drosophilidae (Hochmüller et al. 2010, Poppe et al. 2012, Valer et al. 2013), Sciomyzidae (Kirst et al. 2015), Muscidae (Krüger et al. 2010, Duarte et al. 2010), Mydidae (Duarte and Krüger 2015) and Tabanidae (Krüger and Krolow 2015).

Only 10 Phoridae species are known for the state of Rio Grande do Sul, Brazil (Borgmeier 1968). Therefore, this study aims to better document the phorid fauna of Rio Grande do Sul, by presenting a checklist of species, with their distribution, known to occur in this state. With this objective, we analyzed a large amount of material recently collected in Rio Grande do Sul.

\section{Methods}

The material used in this study was collected by RFK and collaborators in 41 localities along the coastal plains of the Rio Grande do Sul (Fig. 1), mostly through Malaise traps.

Traps were placed around rivulets and streams within forest fragments in the municipalities of Camaquã, Pelo- tas, São Lourenço do Sul, Tavares and Turuçu; they were also placed inside protected preservation areas, namely RPPN Barba Negra, the state parks of Itapeva, Itapuã, and José Lutzemberg (P.E. Guarita), and TAIM Ecological Station. Collecting permits were granted by Instituto Chico Mendes de Conservação da Biodiversidade (ICMBio) and Instituto Brasileiro de Meio Ambiente e dos Recursos Naturais Renováveis (IBAMA). Additional material was collected by Malaise traps in the municipality of Ijuí, northwestern Rio Grande do Sul.

Complete collection data are shown in Figure 1 and Table 1.

Specimens were identified using identification keys and descriptions (Borgmeier 1925, 1962, 1969a, 1969b, 1971, Borgmeier and Prado 1975, Brown 1987, 2004, 2005, Brown and Kung 2007, 2010, Disney, 1994, 2003, 2008, Disney and Bragança 2000, Disney et al. 2006, Hash and Brown, 2015, Uribe et al. 2014) and by comparison with exemplars available in the Phoridae collection of the Museu de Zoologia da Universidade de São Paulo. 
Table 1. Collections sites in Rio Grande do Sul, Brazil date, collectors, locality and geographic coordinates. ${ }^{*}=$ sites with new records for Brazil).

\begin{tabular}{|c|c|c|c|c|c|}
\hline Point & Date & Collector & Locality & Latitude (S) & Longitude (W) \\
\hline $1^{*}$ & 04.xi.2011 & R.F.K., F.D.K. & Pelotas, Arroio Pelotas, Areal, Point 1 & 31.7218 & 052.2542 \\
\hline 2 & 04.xi.2011 & R.F.K., F.D.K. & Pelotas, Arroio Pelotas, Areal, Point 2 & 31.7224 & 052.2537 \\
\hline 3 & 04.xi.2011 & R.F.K., F.D.K. & Pelotas, Arroio Pelotas, Areal, Point 3 & 31.7229 & 052.2531 \\
\hline 4 & 04.xi.2011 & R.F.K., F.D.K. & Pelotas, Arroio Pelotas, Areal, Point 4 & 31.7236 & 052.2529 \\
\hline $5^{*}$ & 04.xi.2011 & R.F.K., F.D.K. & Pelotas, Arroio Pelotas, Mata da Galatéia, Point 1 & 31.6711 & 052.2176 \\
\hline $6^{*}$ & 04.xi.2011 & R.F.K., F.D.K. & Pelotas, Arroio Pelotas, Mata da Galatéia, Point 2 & 31.6721 & 052.2170 \\
\hline 7 & 04.xi.2011 & R.F.K., F.D.K. & Pelotas, Arroio Pelotas, Mata da Galatéia, Point 3 & 31.6732 & 052.2166 \\
\hline 8 & 04.xi.2011 & R.F.K., F.D.K. & Pelotas, Arroio Pelotas, Mata da Galatéia, Point 4 & 31.6742 & 052.2164 \\
\hline 9 & 04.xi.2011 & R.F.K., F.D.K. & Pelotas, Arroio Pelotas, Mata da Galatéia, Point 5 & 31.6741 & 052.2177 \\
\hline 10 & 05.xi.2011 & R.F.K., F.D.K. & Pelotas, Arroio Pelotas, Mata Grande, Point 1 & 31.6278 & 052.3528 \\
\hline $11^{*}$ & 05.xi.2011 & R.F.K., F.D.K. & Pelotas, Arroio Pelotas, Mata Grande, Point 2 & 31.6312 & 052.2830 \\
\hline 12 & 05.xi.2011 & R.F.K., F.D.K. & Pelotas, Arroio Pelotas, Mata Grande, Point 3 & 31.6312 & 052.2830 \\
\hline 13 & 05.xi.2011 & R.F.K., F.D.K. & Pelotas, Arroio Pelotas, Mata Grande, Point 4 & 31.6481 & 052.2512 \\
\hline $14^{*}$ & 06.xi.2011 & R.F.K., F.D.K. & Pelotas, Arroio Corrientes, Fznda. Corrientes, Point 1 & 31.5567 & 052.1456 \\
\hline $15^{*}$ & 06.xi.2011 & R.F.K., F.D.K. & Pelotas, Arroio Corrientes, Fznda. Corrientes, Point 2 & 31.5550 & 052.1433 \\
\hline 16 & 06.xi.2011 & R.F.K., F.D.K. & Pelotas, Arroio Corrientes, Fznda. Corrientes, Point 3 & 31.5533 & 052.1407 \\
\hline 17 & 06.xi.2011 & R.F.K., F.D.K. & Pelotas, Arroio Corrientes, Fznda. Corrientes, Point 4 & 31.5522 & 052.1375 \\
\hline 18 & 07.xi.2011 & R.F.K., F.D.K. & Pelotas, Arroio Corrientes, Dunas, Point 1 & 31.5643 & 052.1395 \\
\hline $19 *$ & 07.xi.2011 & R.F.K., F.D.K. & Pelotas, Arroio Corrientes, Dunas, Point 2 & 31.5642 & 052.1390 \\
\hline $20^{*}$ & 07.xi.2011 & R.F.K., F.D.K. & Pelotas, Arroio Corrientes, Dunas, Point 3 & 31.5647 & 052.1395 \\
\hline $21 *$ & 07.xi.2011 & R.F.K., F.D.K. & Pelotas, Arroio Corrientes, Dunas, Point 4 & 31.5650 & 052.1393 \\
\hline 22 & 08.xi.2011 & R.F.K., F.D.K. & Turuçu, Arroio Grande, Point 1 & 31.4329 & 052.1217 \\
\hline 23 & 08.xi.2011 & R.F.K., F.D.K. & Turuçu, Arroio Grande, Point 2 & 31.4319 & 052.1224 \\
\hline 24 & 08.xi.2011 & R.F.K., F.D.K. & Turuçu, Arroio Grande, Point 3 & 31.4307 & 052.1222 \\
\hline 25 & 08.xi.2011. & R.F.K., F.D.K. & Turuçu, Arroio Grande, Point 4 & 31.4301 & 052.1230 \\
\hline 26 & 08.xi.2011 & R.F.K., F.D.K. & São Lourenço do Sul, Foz do Arroio Grande, Point 1 & 31.4967 & 052.0083 \\
\hline 27 & 08.xi.2011 & R.F.K., F.D.K. & São Lourenço do Sul, Foz do Arroio Grande, Point 2 & 31.4930 & 052.0084 \\
\hline 28 & 08.xi.2011 & R.F.K., F.D.K. & São Lourenço do Sul, Foz do Arroio Grande, Point 3 & 31.4891 & 052.0081 \\
\hline 29 & 08.xi.2011 & R.F.K., F.D.K. & São Lourenço do Sul, Foz do Arroio Grande, Point 4 & 31.4841 & 052.0081 \\
\hline 30 & 27.xi.2011 & R.F.K., F.D.K. & Barra do Ribeiro, RPPN Barba Negra, Mata da faxina, Point 2 & 30.3821 & 051.1169 \\
\hline 31 & 27.xi.2011 & R.F.K., F.D.K. & Barra do Ribeiro, RPPN Barba Negra, Mata da faxina, Point 4 & 30.3626 & 051.1183 \\
\hline 32 & 27.xi.2011 & R.F.K., F.D.K. & Barra do Ribeiro, RPPN Barba Negra, Morro da Formiga, Point 4 & 30.4304 & 051.1410 \\
\hline 33 & 25.xi.2011 & R.F.K., F.D.K. & Camaquã, Pacheca, Rio Camaquã, Point 1 & 31.1215 & 051.7923 \\
\hline 34 & 25.xi.2011 & R.F.K., F.D.K. & Camaquã, Pacheca, Rio Camaquã, Point 3 & 31.1189 & 051.8154 \\
\hline 35 & 20.i.2012 & RFK, FDK,AZS & Viamão, Parque Estadual Itapuã, Mata Grande, Point 1 & 30.3837 & 051.0209 \\
\hline 36 & 22.i.2012 & RFK, FDK,AZS & Torres, Parque Estadual Itapeva, Mata do Morro, Point 1 & 29.3797 & 049.7621 \\
\hline 37 & 22.i.2012 & RFK, FDK,AZS & Torres, Parque Estadual Itapeva, Dunas, Point 1 & 29.3781 & 049.7590 \\
\hline 38 & 22.i.2012 & RFK, FDK,AZS & Torres, P. E. Guarita, Point 1 & 29.3550 & 049.7352 \\
\hline 39 & 22.i.2012 & RFK, FDK,AZS & Torres, P. E. Guarita, Point 3 & 29.3559 & 049.7355 \\
\hline 40 & 12.ii.2012 & R.F.K., F.D.K. & Tavares, Fazenda Boiadeiro, Grande, Point 2 & 31.2136 & 050.9605 \\
\hline 41 & 15.xii.2011 & RFK, FDK,AZS & Rio Grande, ESEC Taim / Nicola, Trevo 150m, Point 3 & 32.5570 & 052.5037 \\
\hline $42^{*}$ & 15.v.2013 & Marques, R. & ljuí, Irder Campo I & 28.4382 & 054.0055 \\
\hline $43^{*}$ & 15.v.2013 & Marques, R. & ljuí, Irder Campo II & 28.4376 & 054.0056 \\
\hline 44 & 15.v.2013 & Marques, R. & ljuí, Irder Mato I & 28.4358 & 054.0093 \\
\hline $45^{*}$ & 15.v.2013 & Marques, $\mathrm{R}$. & ljuí, Irder Milho & 28.4348 & 054.0080 \\
\hline $46^{*}$ & 15.v.2013 & Marques, R. & ljuí, Irder Sorgo & 28.4344 & 054.0081 \\
\hline 47 & 22.v.2014 & Ribeiro, P.S. & Capão do Leão, Horto Botânico Irmão Teodoro Luis & Not available & Not available \\
\hline 48 & 18.iii.2013 & Medeiros, R. & Capão do Leão, Horto Botânico Irmão Teodoro Luis & Not available & Not available \\
\hline
\end{tabular}

Voucher specimens are deposited in the entomological collection Padre Jesus Santiago Moure, Departmento de Zoologia, Universidade Federal do Paraná (DZUP) and in the collection of the Laboratório de Ecologia de Parasitos e Vetores, Departamento de Microbiologia e Parasitologia, Universidade Federal de Pelotas (COLEPAV).

The subfamily classification presented herein follows the phylogeny proposed by Brown et al. (2015).

\section{Results}

A total of 2,187 specimens of phorids belonging to 3 subfamilies, 18 genera, and 41 species were identified. All 41 species are recorded for the first time in the state and Eibsfeldtphora cumsaltensis Disney, 2009, Megaselia (M.) gracilipalpis Borgmeier, 1969, Megaselia (A.) latimanus (Malloch, 1914), Mellaloncha curvata Brown, 
2005, and Trophodeinus vicinus (Borgmeier, 1963) are recorded for the first time in Brazil.

To compare the new and previously published distribution records from the state, Table 2 shows the previous records from Borgmeier's catalogue (1968) for the state. An asterisk (*) denotes a new record for Brazil.

Class Insecta

Order Diptera

Family Phoridae

Subfamily Metopininae

Allochaeta longiciliata Borgmeier, 1926

Allochaeta longiciliata Borgmeier 1926: 46, pl. 2, fig. 5, pl. 3, fig. 8. Allochaeta propinqua Borgmeier 1926: 48, pl. 2, fig. 6; 1928: 120 (syn.)

Material examined. Point 1 (1ठ, DZUP); point 6 (1ठ, DZUP); point 8 (2仓, DZUP); point 14 (4仓ે, DZUP); point

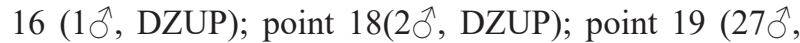

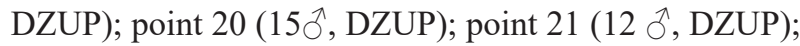

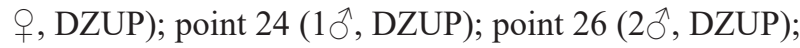
point 27 (3ڤึ, DZUP); point 29 (4仓ે, DZUP).

Diagnostic characters. Foremetatarsus not enlarged; wing with more than 10 pairs of long costal cilia present in costal vein (Borgmeier, 1926).

Distribution. South and southeastern Brazil.

Updated distribution for Brazil. Rio de Janeiro and Rio Grande do Sul.

Apocephalus piliventris Borgmeier, 1925: Figure 5 Apocephalus piliventris Borgmeier 1925: 186, figs. 18-19, pl. 8, fig. 39.

Material examined. Point 3 (2ㅇ, COLEPAV); point 14 (1오, DZUP 459502); point 19 (1, COLEPAV).

Diagnostic characters. This species is recognizable by the structure of the tubular ovipositor, with median furrow.

Distribution. South and southeastern Brazil.

Updated distribution for Brazil. Rio de Janeiro and Rio Grande do Sul.

Apodicrania termitophila (Borgmeier, 1923)

Syneura termitophila Borgmeier 1923: 57, fig. 6.

Apodicrania termitophila-Borgmeier 1933: 384.
Material examined. Point 14 (2 $\widehat{\partial}$, COLEPAV); point

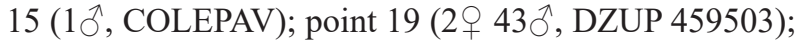

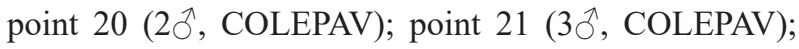

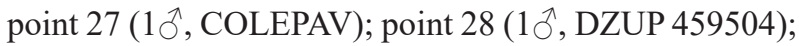
point 29 (2犬̂, COLEPAV)

Diagnostic characters. Dark, shinning body and head color and distinctly divergent fourth and fifth vein.

Distribution. Antilles, Brazil, and Central America.

Updated distribution for Brazil. Minas Gerais, Rio de Janeiro, Rio Grande do Sul and Santa Catarina.

Beckerina luteihalterata Borgmeier, 1925: Figures 6, 7 Beckerina luteihalterata Borgmeier 1925: 132, pl. III, fig. 3.

Material examined. Point 19 (1ð̂, DZUP 459512); point 25 (1ð̄, COLEPAV).

Diagnostic characters. Scutelum with four equal setae; 2 laterally directed supra-antennal setae; anepisternum bare, and yellow colored halters.

Distribution. South and southeastern Brazil.

Updated distribution for Brazil. Rio de Janeiro and Rio Grande do Sul.

*Eibesfeldtphora cumsaltensis Disney, 2009: Figures 8, 9 Eibesfeldtphora cumsaltensis Disney 2009: 605-607, fig. 2.

Material examined. Point 42 (1ㅇ, DZUP 459542); point 43 (1ㅇ, DZUP); point 46 (1요, DZUP 459543).

Diagnostic characters. According to Disney (2009), this species is closely related to E. bragançai and can be distinguished from the later by the less tapered upper lateral lobes of abdominal segment 7 .

Updated Distribution. Argentina and southern Brazil.

Updated distribution for Brazil: Rio Grande do Sul.

Gymnophora (Cerocratia) aemula Borgmeier 1960: Figure 10

Gymnophora (Cerocratia) aemula Borgmeier 1960: 292, fig. 50.

Gymnophora adumbrata Borgmeier, 1960: 291: Brown, 1987.

Material examined. Point 20 (1乞̂, COLEPAV); point 21 (1仓̄, COLEPAV)

Diagnostic characters. Species of this genus can only be reliably determined by the male terminalia. This species

Table 2. Previous known records of Phoridae from Rio Grande do Sul, Brazil (Borgmeier 1968).

\begin{tabular}{ll}
\hline Species & Locality \\
\hline Apocephalus cromatus Borgmeier 1958 & Pareci Novo \\
Cataclinusa bucki Schmitz 1927 & Nova Petrópolis \\
Colobomeles ramboi Borgmeier 1927 & Pareci Novo \\
Conicera megalodus Schmitz 1927 & Porto Alegre \\
Ecitomyia luteola Borgmeier \& schmitz 1923 & Not specified \\
Ecitophora fidelis Borgmeier 1960 & Not specified \\
Ecitoptera ciliata Borgmeier 1923 & Not specified \\
Pseudacteon solenopsidis (Schmitz) 1914 & Porto Alegre \\
Pulliciphora rufipes Silva Figueroa 1916 & Pareci Novo \\
Thalloptera emarginata Schmitz 1935 & Pareci Novo \\
\hline
\end{tabular}




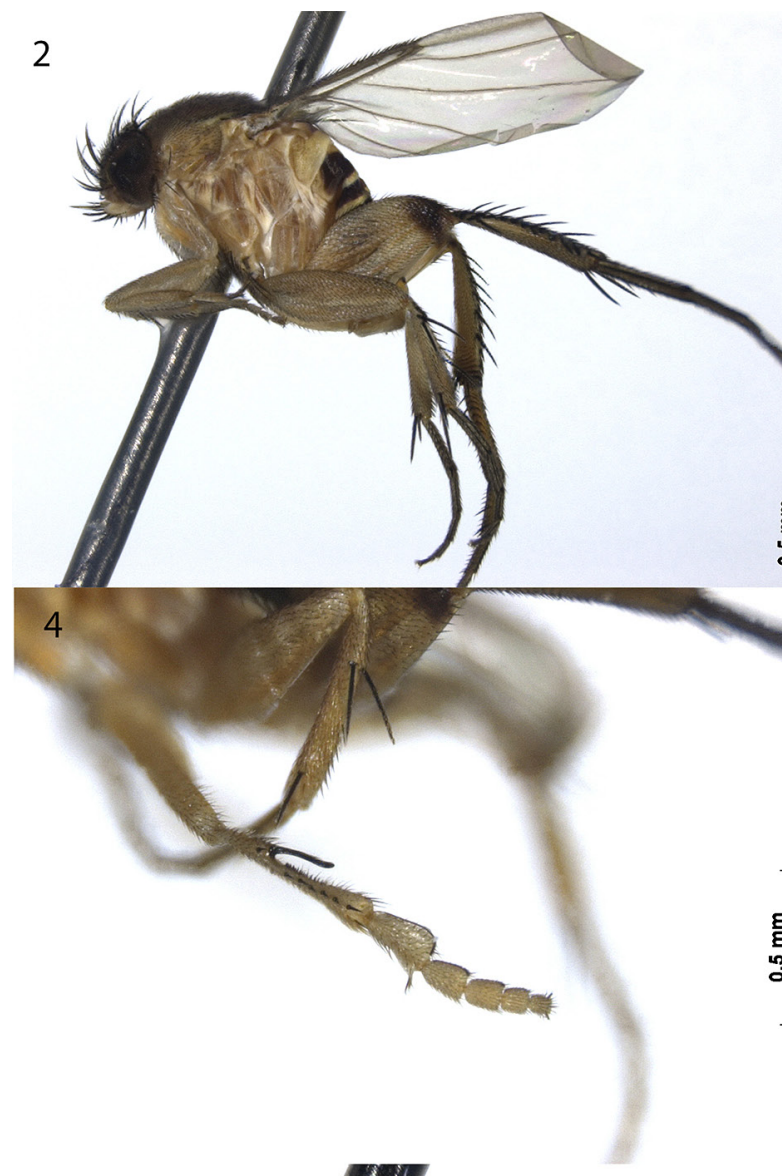

6

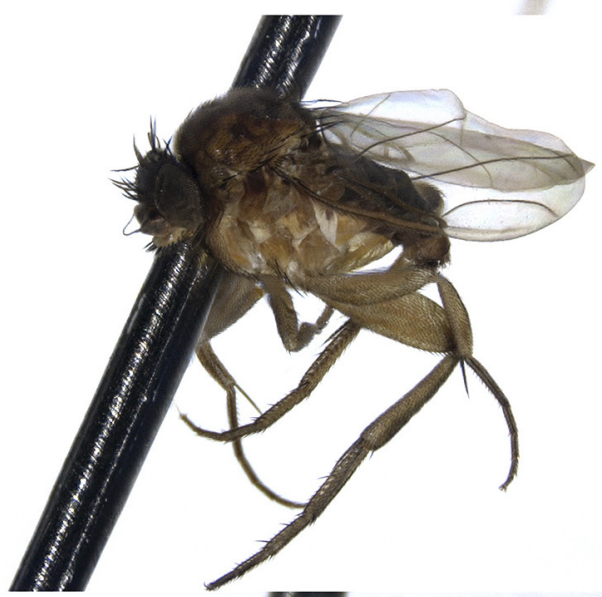

8

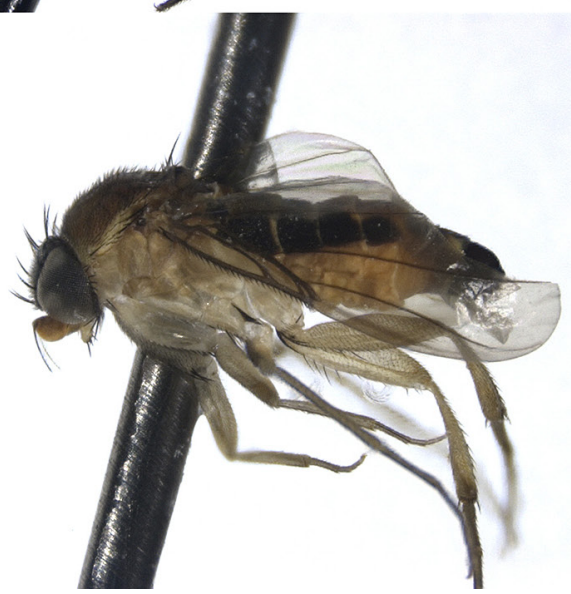

3

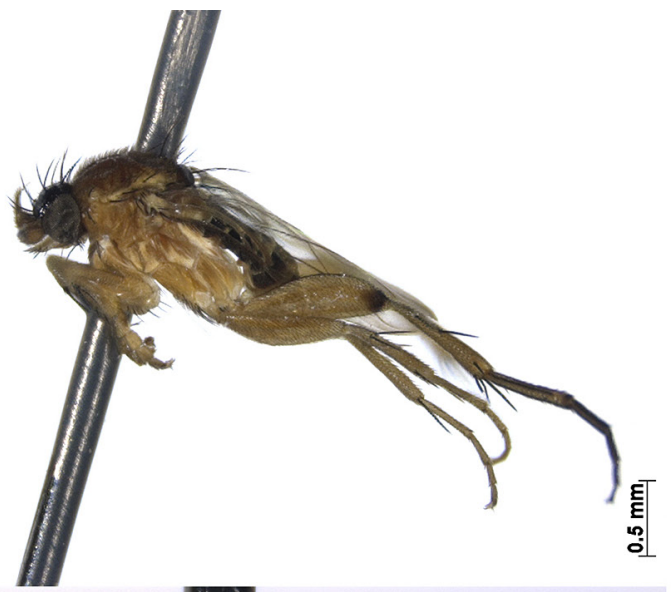

5

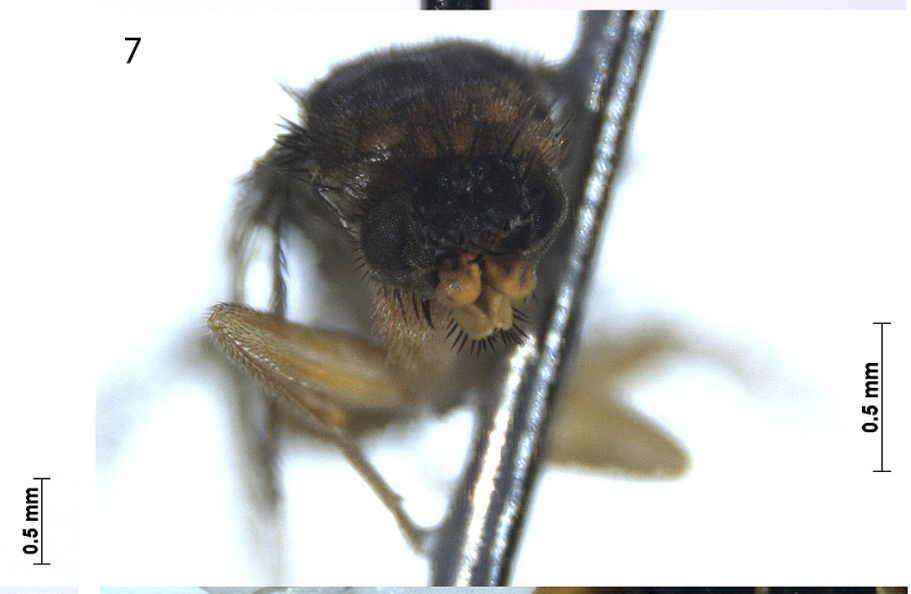

9

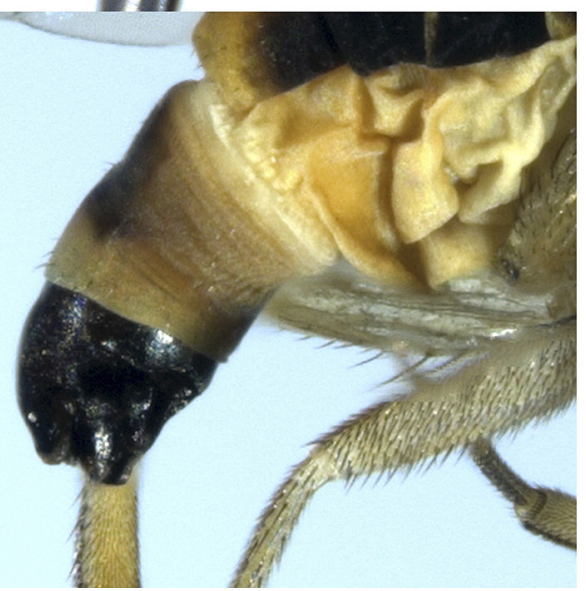

Figures 2-9. 2. Chaetocnemistoptera pityropyga Ament, 2014. 3. Coniceromyia anacleti Borgmeier, 1925. 4. C. anacleti: detail of front tarsus. 5. Apocephalus piliventris Borgmeier, 1925. 6. Beckerina luteihalterata Borgmeier, 1925. 7. B. luteihalterata: head showing the laterally directed supra-antennal setae. 8. Eibesfeldtphora cumsaltensis Disney, 2009. 9. E. cumsaltensis: detail of the ovipositor structure, right lateral view. 
10

12

14

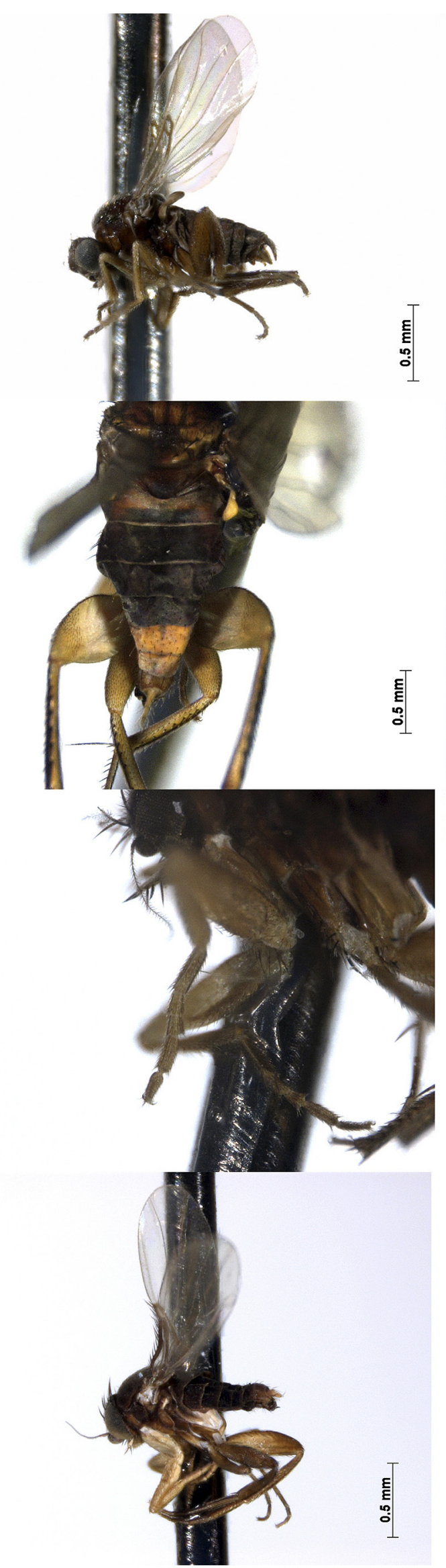

11

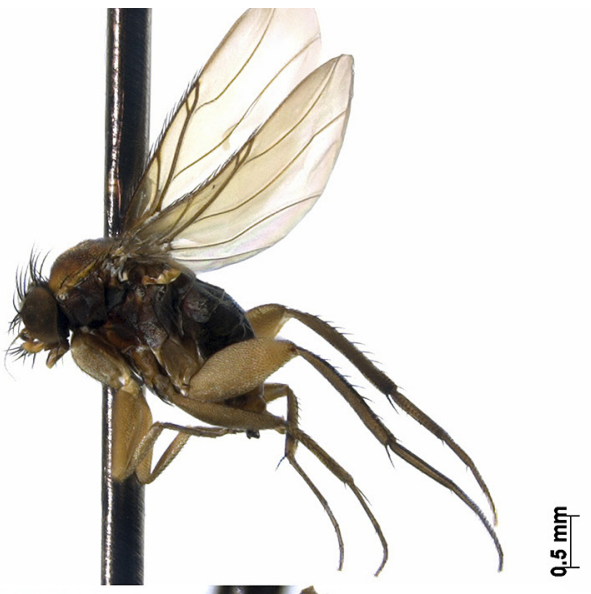

13

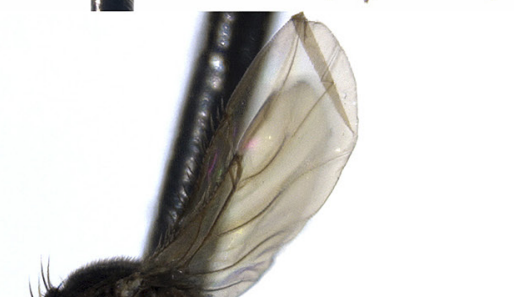

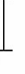

15

17

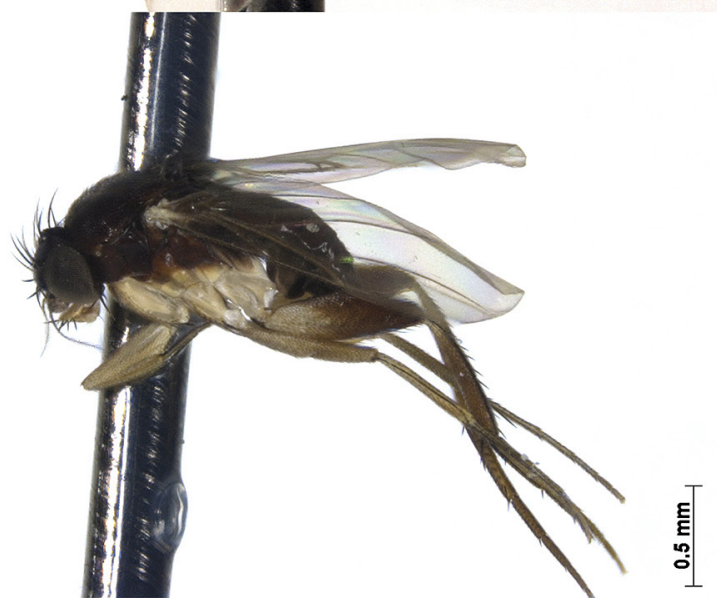

Figures 10-17. 10. Gymnophora (Cerocratia) aemula Borgmeier 1960. 11. Megaselia (A.) castaneipleura Borgmeier, 1969. 12. M. castaneipleura abdomen showing the contrasting orange tergites 5 and 6. 13. Megaselia (A.) latimanus (Malloch, 1914). 14. M. latimanus front tarsus tarsomeres 2 and 3. 15. Megaselia (A.) tumidicosta (Malloch, 1914). 16. Megaselia (A.) tumidula Borgmeier, 1962. 17. Megaselia (M.) femoralis (Enderlein, 1912). 
is distinguished from others by the apex of right surstylus being narrower or of equal width to base and the left surstylus merging with ventral margin of epandrium.

Distribution. Southern Brazil.

Updated distribution for Brazil. Paraná, Rio Grande do Sul and Santa Catarina.

Gymnophora (Gymnophora) brasiliensis Borgmeier 1960 Gymnophora (Gymnophora) brasiliensis Borgmeier 1960: 289, figs 45-46, 56.

Material examined. Point 4 (1乞, COLEPAV); point 6

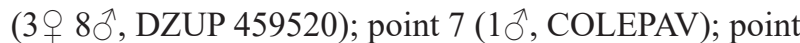
14 (1ㅇ $3 \hat{\jmath}$, COLEPAV); point 15 (2ᄋ $3 \hat{\jmath}$, COLEPAV); point 19 (2ๆ 2へ, COLEPAV); point $21(1 \uparrow 1 \hat{\jmath}$, DZUP 459521); point 24 (1, COLEPAV).

Diagnostic characters. Costal vein thickened, with small constriction in basal third. $\mathrm{R} 2+3$ nearly perpendicular to costa.

Distribution. Southeast and southern Brazil.

Updated distribution for Brazil. Rio de Janeiro, Rio Grande do Sul, Santa Catarina, and São Paulo.

Johowia pilipleura Borgmeier, 1960

Johowia pilipleura Borgmeier 1960: 299, fig. 54.

Material examined. Point $1(1 \propto 4 \hat{\jmath}$, COLEPAV); point

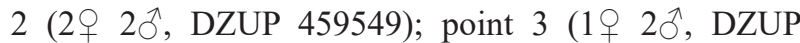

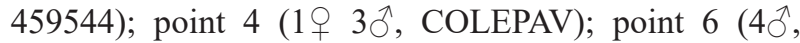
COLEPAV); point 9 (1今, DZUP 459547); point 34 (4우 $3 \hat{\jmath}$, COLEPAV).

Diagnostic characters. Apart from J. hexachaeta Borgmeier, 1960, this is the only other species of the genus with setulae on the anepisternum. It can be distinguished from $J$. hexachaeta by the presence of only 2 setae at the scutelum.

Distribution. South and southeastern Brazil.

Updated distribution for Brazil. Rio de Janeiro and Rio Grande do Sul.

\section{Megaselia (A.) castaneipleura Borgmeier, 1969:}

Figures 11, 12

Megaselia (A.) castaneipleura Borgmeier, 1969: 84-85, figs 67-69.

Material examined. Point 6 (2へ, DZUP 459556); point 19 (4仓̂, DZUP 459559); point 29 (1へ̂, COLEPAV).

Diagnostic characters. This species can be distinguished from all other neotropical Megaselia by the thorax reddish brown and pleura contrastingly dark castaneous Abdominal tergites 1-4 black, 5-6 orange or bright yellow. Hypopygium same color of tergites 5-6.

Distribution. South and southeastern Brazil.

Updated distribution for Brazil. Rio Grande do Sul and São Paulo.

*Megaselia (A.) latimanus (Malloch, 1914):

Figures 13, 14
Aphiochaeta latimanus Malloch 1914: 31.

Megaselia (A.) latimanus-Borgmeier 1962: 304-346, figs 42, 45.

Material examined. Point 6 (20̂, DZUP 459575);

Diagnostic characters. Foretarsomeres 2 and 3 reduced. Foretarsomere 1 is longer than 2 and 3 combined.

Updated Distribution. Southern Brazil and Costa Rica.

Updated distribution for Brazil. Rio Grande do Sul.

Megaselia (A.) luteicauda (Borgmeier, 1925)

Aphiochaeta luteicauda Borgmeier 1925: 145.

Megaselia (A.) luteicauda-Borgmeier 1962: 301.

Material examined. Point 1 (44§, COLEPAV); point

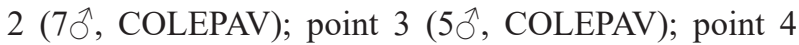

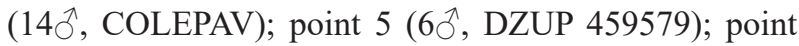
6 (49ðे, COLEPAV); point 7 (10ðे, COLEPAV); point

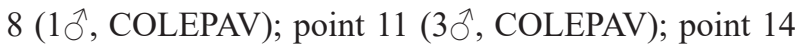

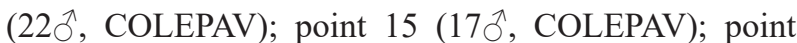

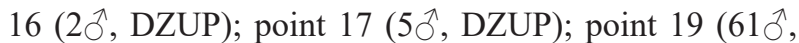
DZUP); point 20 (47ठ, COLEPAV); point 21 (192ð,

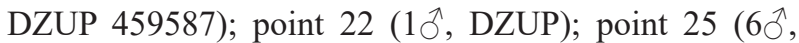

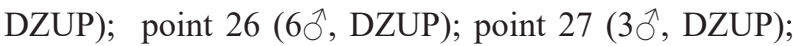

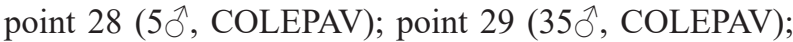
point 31 (5犬̂, DZUP); point 33 (2犬, DZUP); point 34 (1仓, COLEPAV);

Diagnostic characters. Females yellow colored tergites 4-6, contrasting with the dark colored body. Males dark colored, with white halteres; scutelum with 4 equal setae; anepisternum with hairs and 1 or 2 stronger setae; and costal cilia long.

Distribution. South and southeastern Brazil and Dominica.

Updated distribution for Brazil. Pernambuco, Rio de Janeiro, and Rio Grande do Sul.

Megaselia (A.) pauxilla (Brues, 1907)

Aphiochaeta pauxilla Brues 1907: 402, pl. 8, fig. 2.

Megaselia (Aphiochaeta) pauxilla —-Borgmeier 1962: 304-353, figs 48, 52.

Megaselia (Aphiochaeta) excedens Bridarolli, 1940: 492 - Borgmeier, 1962: 353.

Material examined. Point $1(2 \hat{\jmath}$, COLEPAV); point 4 $(1 \hat{\jmath}$, COLEPAV); point 5 (2犬, COLEPAV); point $6(5 \hat{\jmath}$, COLEPAV); point $7(1 \hat{\jmath}$, COLEPAV); point 14 (8ภे,

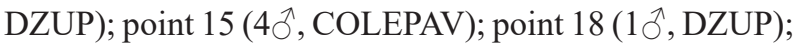

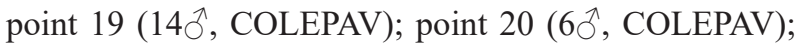
point 21 (29ðे, DZUP); point 24 (2犬̂, COLEPAV); point

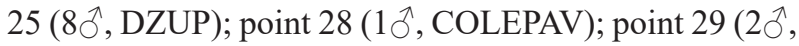
COLEPAV).

Diagnostic characters. This species belongs to the group V of Megaselia, as defined by Borgmeier (1962), among which it can be differentiated by the long costal cilia.

Distribution. Argentina; south and southeastern Brazil.

Updated distribution for Brazil. Rio de Janeiro and Rio Grande do Sul. 
18

20

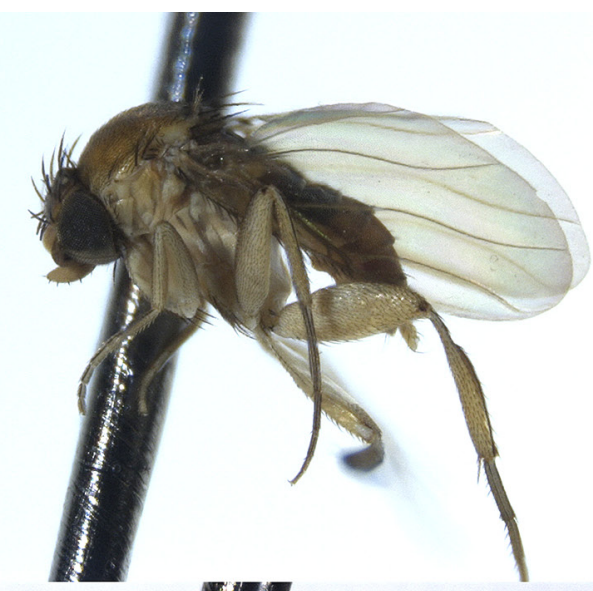

20

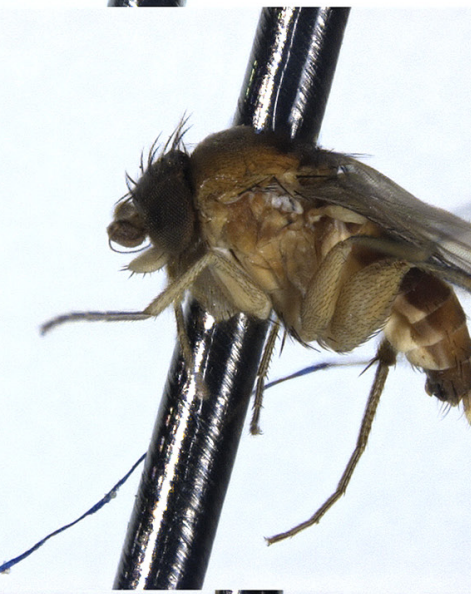

22

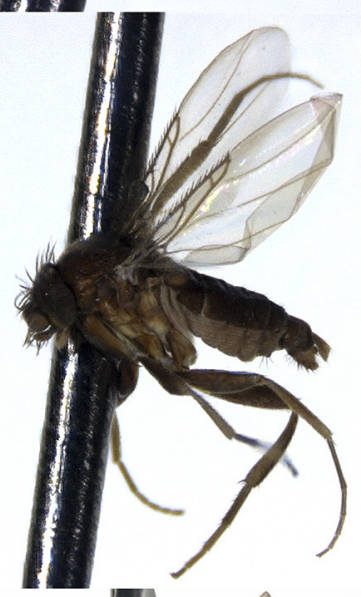

24

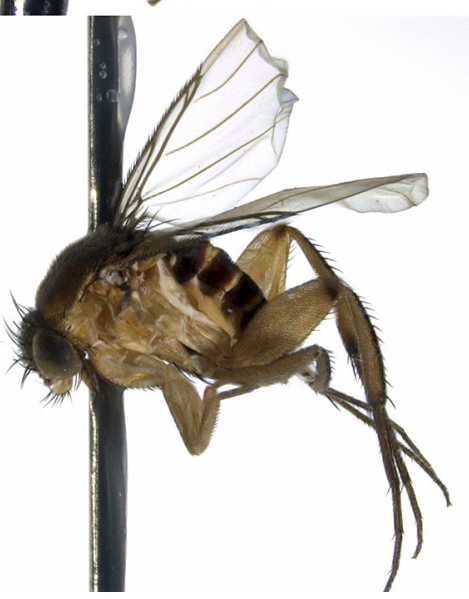

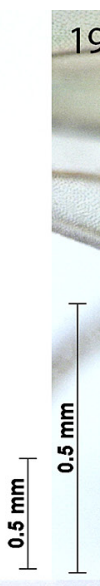

21
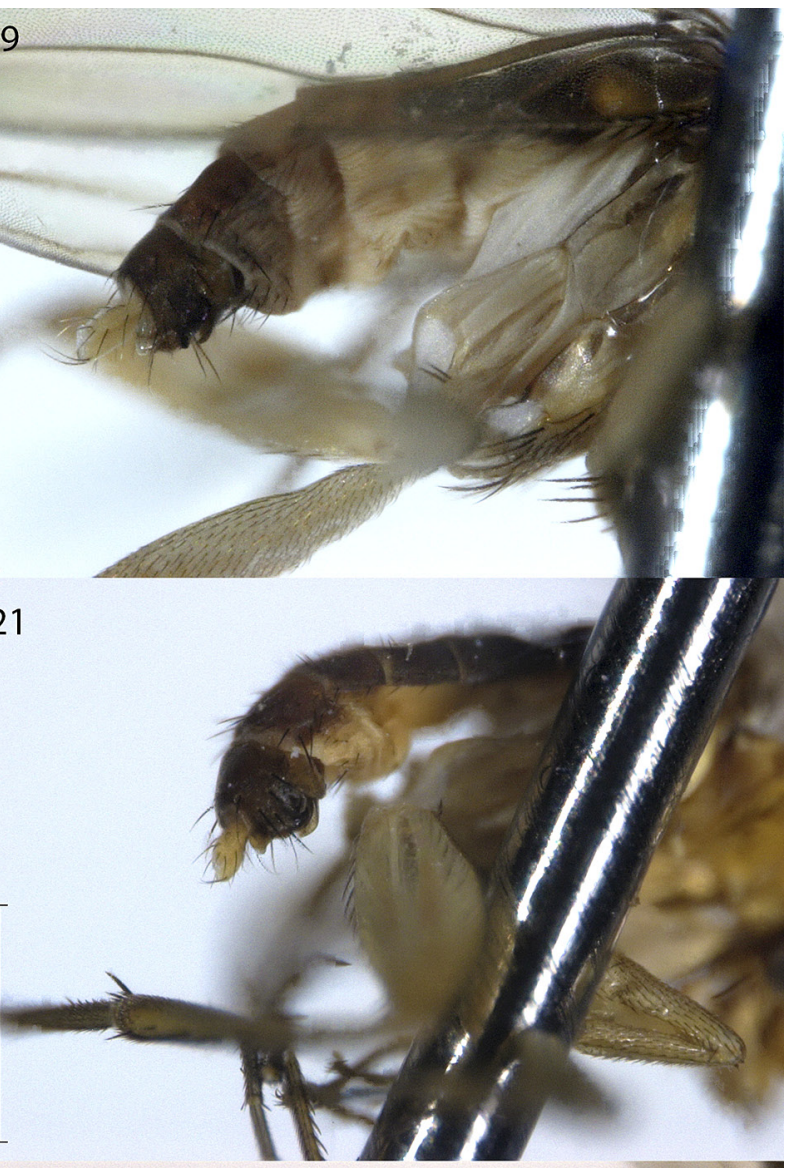

23

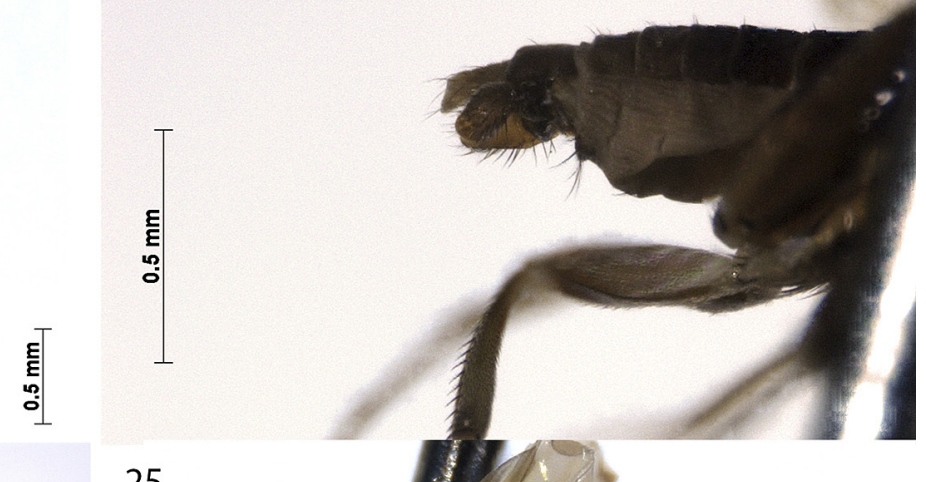

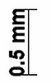

25

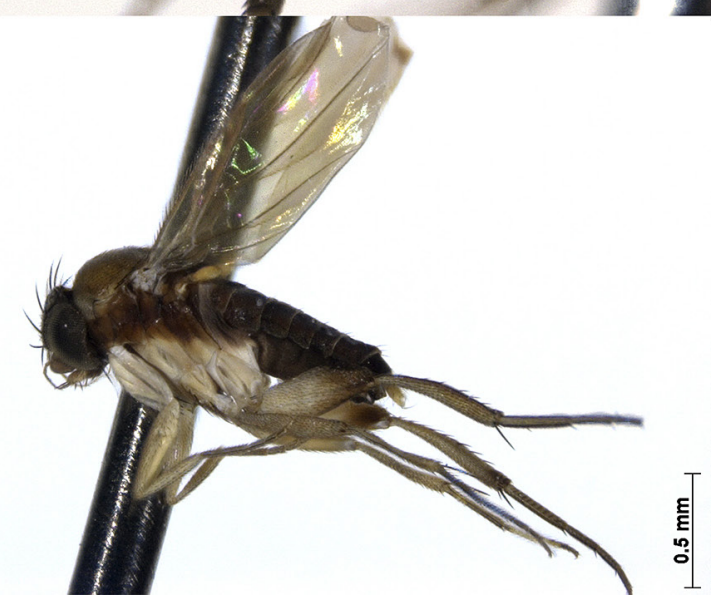

Figure 18-25. 18. Megaselia (M.) gracilipalpis Borgmeier, 1969. 19. M. gracilipalpis: detail of the male genitalia, right lateral view. 20. Megaselia (M.) incarum (Brues, 1915). 21. M. incarum: detail of the male genitalia, right lateral view. 22. Megaselia (M.) notipennis Borgmeier, 1962. 23. M. notipennis: detail of the male genitalia, right lateral view. 24. Megaselia (M.) picta Lehmann, 1822. 25. Megaselia (M.) pleurofascia Borgmeier, 1962. 
Megaselia (A.) sinefurca Borgmeier, 1962

Megaselia (A.) sinefurca Borgmeier, 1962: 303, 332, fig. 23.

Material examined. Point 1 (38今, DZUP 459620); point 2 (3今े, COLEPAV); point $3(9 \hat{\jmath}$, COLEPAV); point 4 (6犬े, COLEPAV); point $5(6 \hat{\jmath}$, COLEPAV); point $6(3 \hat{\jmath}$,

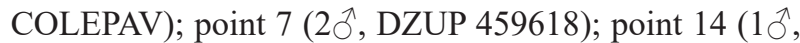

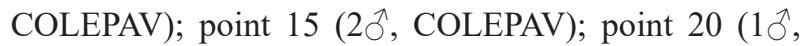
DZUP);

Diagnostic characters. This species belongs to the group III of Megaselia, as defined by Borgmeier (1962). It may be easily distinguished from other species of this group because it is the only species that does not have a thickened costal vein neither the $\mathrm{r} 2+3$ vein.

Distribution. Southern Brazil.

Updated distribution for Brazil. Rio Grande do Sul and Santa Catarina.

Megaselia (A.) tumidicosta Borgmeier, 1962: Figure 15 Megaselia (A.) tumidicosta Borgmeier 1962: 303, 339, fig 30.

Material examined. Point 1 ( $2 \hat{\jmath}$, DZUP 459630); point 3 (1亏, COLEPAV); point 5 (1 $\delta$, COLEPAV); point 6

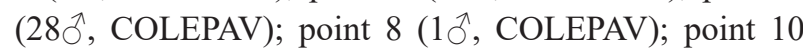

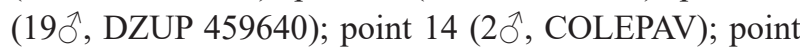
16 (1 $\hat{\jmath}$, COLEPAV); point 20 (2 $\hat{\jmath}$, COLEPAV); point 21 (1 $\widehat{\jmath}$, COLEPAV); point 29 (3今, COLEPAV)

Diagnostic characters. This species belongs to the group III of Megaselia (Borgmeier 1962) and is distinguished from the other species by the thick costal vein and the presence of vein $\mathrm{r} 2+3$.

Distribution. Southern Brazil.

Updated distribution for Brazil. Rio Grande do Sul and Santa Catarina.

Megaselia (A.) tumidula Borgmeier, 1962: Figure 16 Megaselia (A.) tumidula Borgmeier 1962: 303, 338, figs 33, 34.

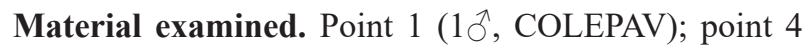
$(1 \widehat{\jmath}, \mathrm{COLEPAV})$; point $5(4 \hat{\jmath}, \mathrm{COLEPAV})$; point $6(25 \hat{\jmath}$, DZUP 459644); point 7 (6ภ, COLEPAV); point 8 (2へ, COLEPAV); point 10 (10今, DZUP 459649); point 14

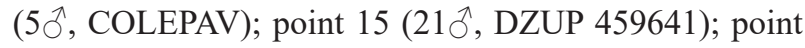

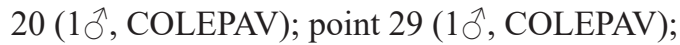

Diagnostic characters. This species belongs to the group III of Megaselia (Borgmeier 1962). It is easily distinguished from other group III species by its thickened costal vein and lacking vein $\mathrm{r} 2+3$.

Distribution. Southern Brazil.

Updated distribution for Brazil. Rio Grande do Sul and Santa Catarina.

Megaselia (M.) femoralis (Enderlein, 1912): Figure 17

Aphiochaeta femoralis Enderlein 1912: 30.

Megaselia (M.) femoralis-Borgmeier 1932: 51.

Material examined. Point 35 (DZUP 459562)
Diagnostic characters. This species belongs to the group VII of Megaselia (Borgmeier 1962). It may be distinguished by the following characters: hind tibia with only posterodorsal row of setae; frons glossy; costal vein not thickened; coxae yellowish-brown; fore and midlegs yellowish-brown; and hind leg dark with the basis of the femur brown-yellow.

Distribution. Brazil, Costa Rica, and United States of America.

Updated distribution for Brazil. Rio Grande do Sul and Santa Catarina.

*Megaselia (M.) gracilipalpis Borgmeier, 1969: Figures 18,19

Megaselia (M.) gracilipalpis Borgmeier 1969: 27, figs 75-77.

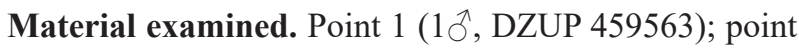
11 (3 $\hat{\jmath}$, COLEPAV); point 14 (3 $\hat{\jmath}$, COLEPAV); point 19

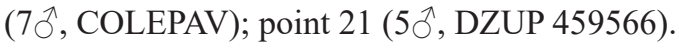

Diagnostic characters. This species belongs to the group VIII of Megaselia (Borgmeier 1962). It is very easily recognizable by the slender palpi with very short setulae and fine hairs and the structure and chaetotaxy of the hypopygium.

Distribution. Southern Brazil and Dominica.

Updated distribution for Brazil. Rio Grande do Sul.

Megaselia (M.) incarum (Brues, 1915): Figures 20, 21 Aphiochaeta incarum Brues 1915: Appendix.

Megaselia (M.) incarum-Borgmeier 1962: 312, 449, fig. 100.

Material examined. Point 19 (5今े, DZUP 459571); point 21 (2ð, COLEPAV); point 29 (10, COLEPAV).

Diagnostic characters. This species belong to the group VIII of Megaselia species (Borgmeier, 1962). It is very similar to M. gracilipalpis with the structure and setation of the palpi very similar. It can be distinguished from the latter by the chaetotaxy of the hypopygium with much stronger and fewer setae (Figure 21).

Distribution. Argentina; south and southeastern Brazil; Peru.

Updated distribution for Brazil. Rio de Janeiro, Rio Grande do Sul, and Santa Catarina.

Megaselia (M.) notipennis Borgmeier, 1962:

Figures 22, 23

Megaselia (M.) notipennis Borgmeier 1962: 310, 422, figs 72, 80-81.

Material examined. Point 1 (30 $\widehat{\jmath}, \mathrm{COLEPAV})$; point 2

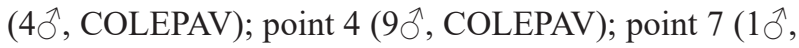
COLEPAV); point 10 (1 $\hat{O}^{\hat{2}}$, COLEPAV); point $14(2 \hat{\jmath}$,

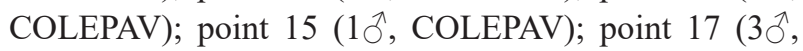
COLEPAV); point 19 (66^, COLEPAV); point 20 (5 $\hat{\jmath}^{\lambda}$,

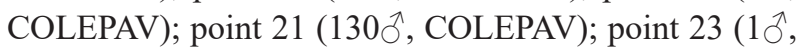
COLEPAV); point 24 (1 $\hat{0}$, COLEPAV); point $25(6 \hat{0}$,

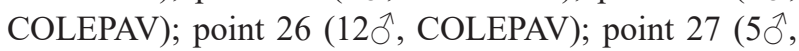

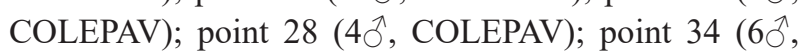
COLEPAV). 
Diagnostic characters. This species belongs to the group VII of Megaselia (Borgmeier 1962). This is a very striking species, easily recognizable by the unique morphology of the asymmetrical hypopygium with 2 expanded lobes. Right lobe large, spoon shaped, hollowed out in the inside face; and left lobe smaller, bifurcated.

Distribution. Argentina; south and southeastern Brazil.

Updated distribution for Brazil. Rio de Janeiro, Rio Grande do Sul, and Santa Catarina.

Megaselia (M.) picta Lehmann, 1822: Figure 24

Phora picta Lehmann 1822: 43, pl. 1, fig. 6.

Aphiochaeta picta-Brues 1904: 361, pl. 7, fig. 28.

Megaselia (M.) picta—Schmitz 1929: 20, 23, 187.

Trineura interrupta Zetterstedt 1838: 797.

Phora interrupta-Schiner 1864: 337.

Trineura subquadrifasciata Zetterstedt 1852: 4826.

Aphiochaeta atlantica Brues 1904: 362, pl. 7, fig. 30.

Megaselia (M.) atlantica: Brues, 1950: 73 - Borgmeier, 1961: 110.

Megaselia (M.) infuscata Bridarollli 1940: 487-Borgmeier 1962: 296.

Material examined. Point 1 (15つ, DZUP 459593); point

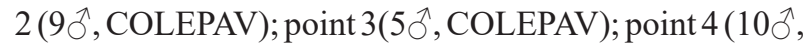

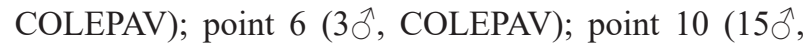

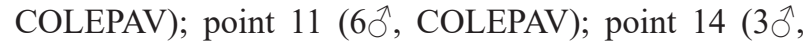
COLEPAV); point 15 (10 $\hat{\jmath}$, COLEPAV); point 16 (1ڤ, COLEPAV); point 17 (17ð, COLEPAV); point 19 (198ð, DZUP 459608); point 20 (115ð̄, COLEPAV);point 21 (298ð̄, DZUP 459589); point 23 (1ठ, COLEPAV); point 25 (11 $\hat{\jmath}$, COLEPAV); point $26(8 \hat{\jmath}$, COLEPAV); point 28 (2犬̂, COLEPAV); point $29(18 \hat{\jmath}$, COLEPAV); point 31 (4ふે, COLEPAV); point 33 (2へ̂, COLEPAV); point 34 (1へ, COLEPAV).

Diagnostic characters. This species belongs to groups VI or VII of Megaselia (Borgmeier 1962). This is a large, mostly yellow species. The number of scutellar setae is variable in this species (2-4), although in our specimens the presence of 4 equal scutellar setae were rare. Lower inter-frontal setae placed in the eye margin, close to the lower fronto-orbital setae. Abdominal tergites yellow with black bands usually interrupted on tergites 3-5 in the center. Hind tibia with strong posterodorsal setae; and anterodorsal setae shorter and variable in number.

Distribution. Europe; North and South America; and Oceania.

Updated distribution for Brazil. Rio de Janeiro, Rio Grande do Sul, and Santa Catarina.

Megaselia (M.) pleurofascia Borgmeier, 1962: Figure 25 Megaselia (M.) pleurofascia Borgmeier, 1962: 310, 418.

Material examined. Point 1 (1ふ,, DZUP 459613); point 4 (1ふ̄; COLEPAV); point 11 (1ڤ̂, COLEPAV); point 17 (1亏, DZUP 459614);

Diagnostic characters. This species belongs to the group VII of Megaselia species (Borgmeier, 1962). It is easily recognizable by the light brown scutum and a broad dark stripe in the pleura, with the humeral area lighter. Legs brown-yellow and hind femur with an apical brown spot.
Distribution. Southern Brazil and West Indies.

Updated distribution for Brazil. Rio Grande do Sul and Santa Catarina.

*Melaloncha curvata Brown, 2005: Figure 27

Melaloncha curvata Brown 2005: 246-247, figs 4, 35.

Material examined. Point 45 (1 9 , DZUP).

Diagnostic characters. This species belongs to the $M$. furcate-group (Brown, 2005) and can be easily separated from all other species by the strongly curved ovipositor.

Updated Distribution. Argentina and southern Brazil.

Updated distribution for Brazil. Rio Grande do Sul.

Melaloncha ronnai Borgmeier, 1935: Figure 26

Melaloncha ronnai Borgmeier 1935: 262, fig. 14.

Material examined. Point 45 (1옹, DZUP 459650).

Diagnostic characters. This species belongs to the udamochiras group (Brown 2004) and can be distinguished from the other species of that group by the narrow, elongate ovipositor, with extremely short and sparse setae.

Distribution. Guatemala to Argentina.

Updated distribution for Brazil. Distrito Federal, Minas Gerais, Rio de Janeiro, Rio Grande do Sul, and Santa Catarina.

Myriophora uruguaiensis Hash \& Brown, 2015: Figure 28 Myriophora uruguaiensis Hash and Brown 2015: 47-48, figs 8.6, 14.6, $20.5,21.16$

Material examined. Point 19(3 9 , DZUP 459653); point 20 (1q, COLEPAV); point 21 (3․ DZUP 459651).

Diagnostic characters. Species of this genus can only be determined in the female sex. M. uruguaiensis can be distinguished from the others by the long, thin, weakly laterally compressed oviscape with sternite only about $1 / 4$ to $1 / 3$ as long as tergite and about twice as wide.

Distribution. Argentina; south and southeastern Brazil.

Updated distribution for Brazil. Minas Gerais and Rio Grande do Sul.

Myrmosicarius catharinensis Borgmeier, 1928

Myrmosicarius catharinensis Borgmeier 1928: 124.

Myrmosicarius cuspidatus Borgmeier 1928: 124_Disney et al. 2006: 778.

Material examined. Point 42 (2q, COLEPAV).

Diagnostic characters. This species is recognizable by the apical portion of the ovipositor which is strongly tapered and pointed at the tip.

Distribution. Argentina and Brazil.

Updated distribution for Brazil. Rio de Janeiro, Rio Grande do Sul, Santa Catarina, and Tocantins.

Pseudacteon litoralis Borgmeier, 1925: Figure 29

Pseudacteon litoralis Borgmeier 1925: 247, fig. 51.

Material examined. Point 43 (1 9 , DZUP). 


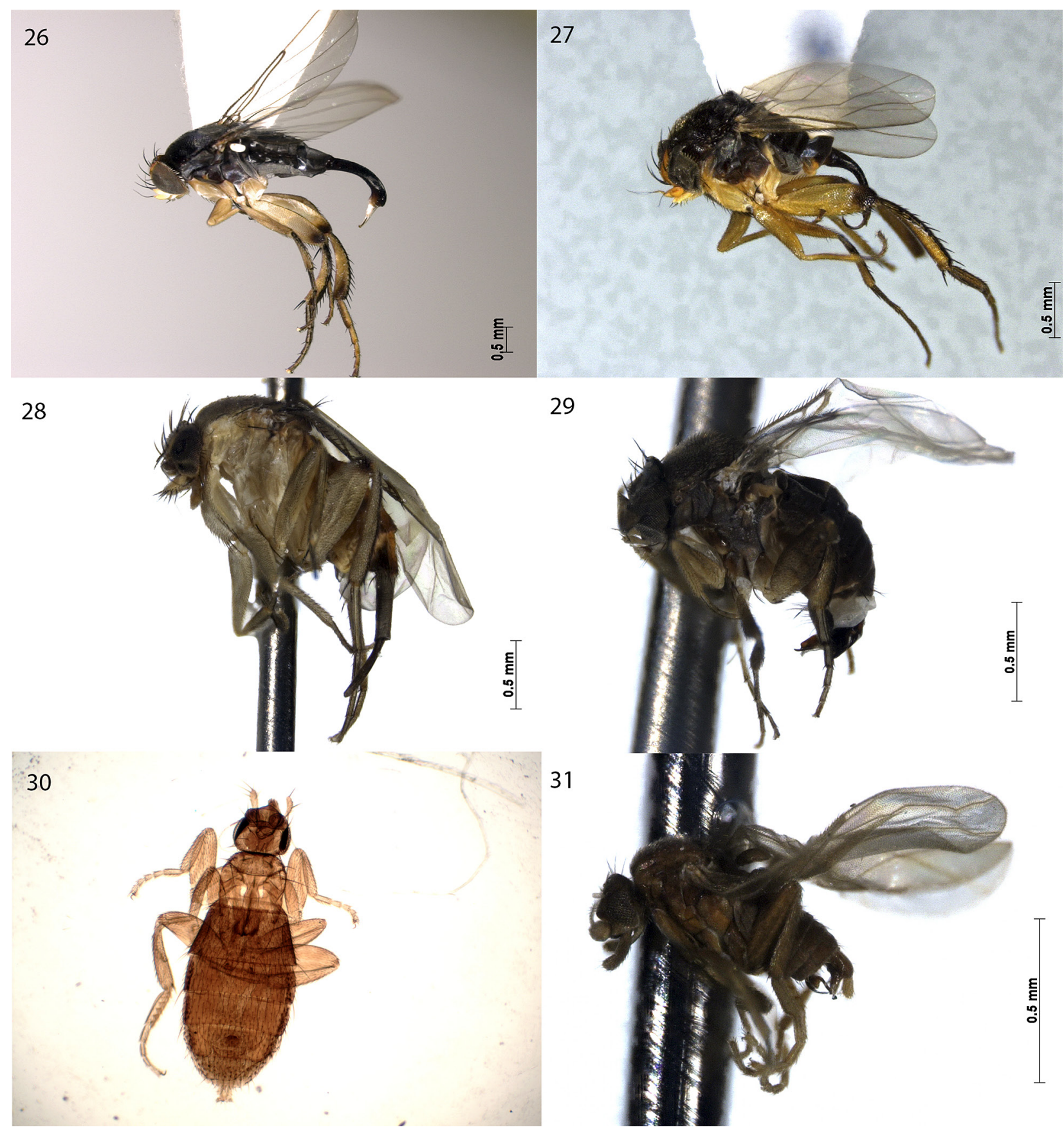

Figure 26-31. 26. Melaloncha ronnai Borgmeier, 1935. 27. Melaloncha curvata Brown, 2005. 28. Myriophora uruguaiensis Hash \& Brown, 2015. 29. Pseudacteon litoralis Borgmeier, 1925. 30. Puliciphora borinquenensis Wheeler, 1906. 31. Trophodeinus vicinus (Borgmeier, 1963).

Diagnostic characters. This species is easily recognized by the structure of the tricuspidate ovipositor.

Distribution. Argentina and Brazil.

Updated distribution for Brazil. Mato Grosso, Paraná, Rio Grande do Sul, and São Paulo.

Puliciphora borinquenensis Wheeler, 1906 Figure 30 Puliciphora borinquenensis Wheeler 1906: 269, pl. 34.

Material examined. Point 48 (14우, DZUP).

Diagnostic characters. Species characterized by the well-developed T6; flap of T5 longer than midline length of the rest of tergite; T3 and T4 shorter than T2.

Distribution. Pantropical.
Updated distribution for Brazil. Espírito Santo, Goiás, Pernambuco, Rio de Janerio, Rio Grande do Sul, Santa Catarina, and São Paulo.

*Trophodeinus vicinus (Borgmeier, 1963): Figure 31 Bactropalpus vicinus Borgmeier 1963: 169, fig. 8. Trophodeinus vicinus-Brown 1986: 787-788.

Material examined. Point 1 ( $1 \widehat{\jmath}$, COLEPAV); point 5

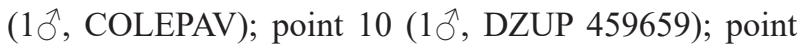
14 (4ð, DZUP 459656); point 15 (1ð,, COLEPAV); point 19 (7ठे, COLEPAV); point 20 (2ð, COLEPAV); point 21 (1ふै, DZUP 459658);

Diagnostic characters. This species is easily recognized by the structure of the asymmetrical hypopygium. Left 
forceps broad at base, tapering towards apex; and right forceps bent near base, distal part slightly sinuous, apex rounded (Borgmeier 1963).

Updated Distribution. Southern Brazil and Guatemala. Updated distribution for Brazil. Rio Grande do Sul.

Subfamily Phorinae

Chaetocnemistoptera pityropyga Ament, 2014: Figure 2 Chaetocnemistoptera pityropyga Ament 2014: 315-317, figs 8, 29, 39-40, 63-66.

Material Examined. Point 14 (1ふ, COLEPAV); point 19 (1仓̂, COLEPAV); point 21 (3仓̂, DZUP 459513).

Diagnostic characters. This species can be distinguished from the other species of Chaetocnemistoptera by the lack of lobes or well-defined groups of setulae in the hind femur and the presence of a lateral row of rounded protuberances in the hypandrium.

Distribution. Southern Brazil, northern Argentina, and Ecuador.

Updated distribution for Brazil. Paraná, Rio Grande do Sul, and Santa Catarina.

Coniceromyia anacleti Borgmeier, 1925: Figures 3, 4 Coniceromyia anacleti Borgmeier 1925: 123-125, fig. 8 .

Material examined. Point 1 (5 $\hat{\jmath}$, DZUP 459517); point 11 (1ふึ, DZUP); point 24 (1ふึ, DZUP 459515); point 25 (1へ, DZUP 459516); point 35 (1ڤึ, DZUP).

Diagnostic characters. This species is easily recognized by the characteristic setation of the foretibia, with 1 strong, sinuous postero-dorsal spine, followed by a row of 6 or 7 strong dorsal setae. The front metatarsus is strongly dilated, with an anterior excavation followed by an anteroapical process.

Distribution. Northeastern Argentina, southern states in Brazil, and areas of higher altitudes in southeastern Brazil (Ament and Amorin 2016).

Updated distribution for Brazil. Espirito Santo, Paraná, Rio Grande do Sul, Santa Catarina, São Paulo.

Dohrniphora biseriata Borgmeier, 1960 Dohrniphora biseriata Borgmeier 1960: 284, fig. 39.

Material examined. Point 36 (1ठ઼, COLEPAV).

Diagnostic characters. This species is easily recognizable by the double line of peg-like setae along the ventral margin at the base of posterior face of the hind femur (Brown and Kung 2010, figs. 183, 184).

Distribution. South America.

Updated distribution for Brazil. Manaus, Rio de Janeiro, and Rio Grande do Sul.

Dohrniphora canaliculata Borgmeier, 1960

Dohrniphora canaliculata Borgmeier 1960: 286-287, fig. 42.

Material examined. Point 14 (1つ̂, DZUP 459530); point
15 (1ð, COLEPAV); point 28 ( $1 \lesssim$, DZUP 459529); point 36 ( $1 \hat{\sigma}$, COLEPAV).

Diagnostic characters. This species is recognizable by a basal group of peg-like setae placed on a rounded lobe, followed by an elongate, tapered concavity at the base of posterior face of the hind femur (Brown and Kung 2010: figs 227, 228).

Distribution. South and southeastern Brazil.

Updated distribution for Brazil. Rio de Janeiro, Rio Grande do Sul and Santa Catarina.

\section{Dohrniphora cornuta (Bigot, 1857)}

Phora cornuta Bigot 1857: 348 (French edition: 1857: 827).

Diploneura (Dohrniphora) cornuta-Schmitz 1926: 44.

Dohrniphora cornuta —Borgmeier 1960: 277, fig. 28.

Phora navigans Frauenfeld 1867: 154.

Phora cleghorni Bigot 1890: 191.

Phora chlorogastra Becker 1901: 32.

Phora mordax Brues 1911: 531, fig. 1.

Dohrniphora venusta Malloch 1912: 432.

Dohrniphora bequaerti Schmitz 1914: 105, fig. 1.

Apocephalus flaviventris Silva Figueroa 1916: 15, fig. 8.

Dohrniphora divaricata var. basalis Santos Abreu 1921: 11.

Dohrniphora divaricata var. obscura Santos Abreu 1921: 11.

Dohrniphora fulva Santos Abreu 1921: 12, fig. AB, pl. 1, fig. 1.

Dohrniphora opposita Borgmeier 1925: 107, pl. 2, fig. 6; 1960: 277.

Dohrniphora crockeri Van Duzee 1933: 70.

Dohrniphora willowsi Van Duzee 1933: 70.

Dohrniphora cavifemur Borgmeier 1969: 1-2 (in part, male only), misidentification.

Material examined. Point 48 ( $3 \curvearrowright$, COLEPAV).

Diagnostic characters. This species is easily recognizable by the small group of peg-like setae on the base of the posterior face of the hind femur and the thin setae on dorsal surface (Brown and Kung 2010: figs 25, 26).

Distribution. Cosmopolitan.

Updated distribution for Brazil. Rio de Janeiro and Rio Grande do Sul.

\section{Dohrniphora diplocantha Borgmeier, 1960}

Dohrniphora diplocantha Borgmeier 1960: 268, fig. 12.

Material Examined. Point 15 (3ڤ̂, DZUP 459531); point 30 (4仓ે, COLEPAV); point 32 (1今̂, COLEPAV).

Diagnostic characters. Posterior face of hind femur with a single row of about 6 peg-like setae along ventral margin and a more dorsal group of about 20; and distally with a small transverse carina. Hind tibia with 2 anterodorsal setae (Brown and Kung 2007, figs 63-64, 208).

Distribution. South and southeastern Brazil.

Updated distribution for Brazil. Minas Gerais, Rio Grande do Sul, Rondônia, Santa Catarina, and São Paulo.

Dohrniphora dispar (Enderlein, 1912)

Phora dispar Enderlein 1912: 29-30.

Dohrniphora dispar - Schmitz 1923: 55-56.

Material examined. Point $39(1 \hat{\jmath}$, DZUP); point $40(1 \hat{\jmath}$, DZUP). 
Diagnostic characters. This species is easily recognizable by the orange, enlarged flagellomere 1 and the large and darkened foretarsomere 5. The posterior face of the hind femur has a group of about 60 peg-like setae followed by a dorsally opened concavity (Brown and Kung 2010, figs 195-196).

Distribution. Widespread in New World tropical lowlands.

Updated distribution for Brazil. Amapá, Rio de Janeiro, Rio Grande do Sul, and Santa Catarina.

Dohrniphora divaricata (Aldrich, 1896)

Phora divaricata Aldrich 1896: 437.

Dohrniphora divaricata-Borgmeier 1961: 111.

Dohrniphora obscuriventris Borgmeier 1925: 105. Synonymized by Disney and Kistner 1997: 24.

Dohrniphora diffusa Borgmeier 1960: 281-282, fig. 35; 1961: 111.

Dohrniphora recurvata Borgmeier 1960: 272, fig. 20- Brown and Kung 2010: 91

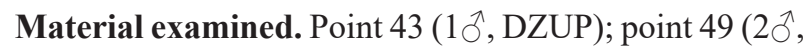
DZUP).

Diagnostic characters. This species varies extensively on the number and disposition of the peg-like setae. According to Kung and Brown (2006) the posterior face of the hind femur has usually 2 rows along the ventral margin, in addition to a larger group of setae dorsal to that row (Kung and Brown 2006, figs 5-12, 20, 27-28). Our specimens are very similar to those illustrated by Borgmeier and Prado (1975: fig. 27) as D. obscuriventris.

Distribution. Widespread in the New World tropical lowlands to the United States of America.

Updated distribution for Brazil. Paraná, Rio de Janeiro, Rio Grande do Sul, and Santa Catarina.

Dohrniphora fuscicoxa Borgmeier, 1923

Dohrniphora fuscicoxa Borgmeier 1923: 327-329.

Material examined. Point 19 (10ิ, DZUP); point 21 (1ふ, DZUP 459533); point 31(1ð, DZUP); point 41 (2へ, DZUP).

Diagnostic characters. This species is easily recognizable by the contrastingly darker midcoxa. Peg-like setae distributed as a tringle at base of hind femur, followed by 2 dorsoventral carina (Brown and Kung 2010: figs 245, 246).

Distribution. South America.

Updated distribution for Brazil. Pernambuco, Rio de Janeiro, Rio Grande do Sul, Santa Catarina, and São Paulo.

Dohrniphora longirostrata (Enderlein, 1912)

Crepidopachys longirostrata Enderlein 1912: 17, fig. 1.

Dohrniphora longirostrata-Malloch 1913: 23.

Diploneura (Dohrniphora) longirostrata-Schmitz 1929: 78, 107-108.

Dohrniphora ronchii Borgmeier 1923: 52.

Crepidopachys ronchii Enderlein 1924 : 49.

Diploneura (Dohrniphora) ronchii Schmitz 1929: 31, 108.
Material examined. Point 36 (5ภ, DZUP 459534).

Diagnostic characters. This species is distinguished from the other longirostrata-group species by the yellow pleura and scutum. The posterior face of the hind femur has 3 long, thick proximal setae. Proximal apex narrowed, dorsally directed (Kung and Brown 2005: fig. 1)

Distribution. Northern Argentina to midwest and southeastern Brazil.

Updated distribution for Brazil. Distrito Federal, Minas Gerais, Rio Grande do Sul, Santa Catarina.

Dohrniphora lugens Borgmeier, 1960

Dohrniphora lugens Borgmeier 1960: 286, fig. 44.

Material examined. Point 33 (2ڤึ, DZUP 459538).

Diagnostic characters. This is a dark colored species easily recognizable by the elongate group of three to four rows of peglike setae and the presence of a clear spot at the ventral margin of the hind femur (Brown and Kung 2010L figs 205, 206, 301).

Distribution. Argentina to Costa Rica.

Updated distribution for Brazil. Rio Grande do Sul, Santa Catarina.

\section{Dohrniphora paraguayana (Brues, 1907)}

Phora paraguayana Brues 1907: 400-401, pl. 8 fig. 9.

Dohrniphora paraguayana-Brues 1915: 96; Borgmeier 1960: 269, fig. 13.

Diplonevra (Dohrniphora) paraguayana—Schmitz 1929: 108.

Dohrniphora conspicua Borgmeier 1923: 628; 1925: 99-101, pl. 1 fig. 2.

Diploneura (Dohrniphora) conspicua —Schmitz 1929: 108; Brues 1932: 134.

Diploneura (Dohrniphora) anterodorsalis Schmitz 1928: 28-29; 1929 : 108.

Material examined. Point 45 (1ð, DZUP 459541); point 46 (3ڤึ, DZUP 459539); point 44 (1ڤึ, DZUP)

Diagnostic characters. This species is easily recognizable by the hind tibia setation with a row of several antero-dorsal setae and by the three closely-placed peglike setae near the ventral margin of the posterior face of hind femur (Brown and Kung 2007: figs. 89-90, 223).

Distribution. New World tropics.

Updated distribution for Brazil. Amapá, Amazonas, Espirito Santo, Maranhão, Mato Grosso, Minas Gerais, Rio de Janeiro, Rio Grande do Sul, Rondônia, Roraima, and São Paulo.

\section{Subfamily Chonocephalinae}

Chonocephalus depressus Meijere, 1912

Chonocephalus depressus Meijere 1912: 151 (female)—Disney 1991: 208 (male).

Chonocephalus similis-Collin 1912: 105 (part) nec Brues, 1905. Misidentification, Disney 2002: 14.

Chonocephalus ecitophilus Borgmeier \& Schmitz 1923: 145-Disney 2002: 14.

Chonocephalus japonicus Schmitz 1941: 82 (part), fig. of male wing only; Disney 2002: 15. 
Chonocephalus dimakae Paulian 1958: 12-Disney 2005: 406.

Chonocephalus pallidulus Beyer in Hardy and Beyer 1964: 298_-Disney 2002: 15.

Chonocephalus simiolus Beyer in Hardy and Beyer 1964: 300-Disney, 2002: 15

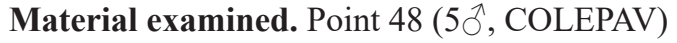

Diagnostic characters. This species is easily recognized by the structure of the hypopygium (Disney 2008: figs $33,34)$.

Distribution. Cosmopolitan.

Updated distribution for Brazil. Rio Grande do Sul and Santa Catarina.

\section{Discussion}

This is the first attempt to compile data on phorid distribution from the state of Rio Grande do Sul. The lack of studies on this subject is evidenced by the great increase in the number of species registered here for the state. Our survey revealed a diversity 5 times higher than previously known (Borgmeier 1968).

Megaselia Rondani 1856, with 13 species recorded, is the most diverse genus in Rio Grande do Sul. This is the largest genus of the family and accounts for nearly half of the described species (Brown 2010). The total diversity for the state should be much higher, but because of the many undescribed species and the few and scattered taxonomic works, the correct determination of species becomes complicated. At least 24 more species of Megaselia were collected in Rio Grande do Sul and could not be identified.

The second most diverse genus was Dohrniphora Dahl, with 10 species collected. This is one of the best-known genera of the family with 2 comprehensive taxonomic revisions (Brown and Kung 2007, 2010). This genus currently has 227 species described, of which 114 occur in Brazil.

Melaloncha curvata and Eibsfeldtphora cumsaltensis were previously recorded from Argentina and are registered for the first time in Brazil. Megaselia gracilipalpis, M. latimanus, and Trophodeiunus vicinus were previously recorded from Dominica, Costa Rica, and Guatemala, respectively, and are also first recorded from Brazil.

Apart from the species mentioned in this study, a specimen belonging to the genus Zikania Borgmeier, 1925 was also collected in the state. The current taxonomy of the group does not allow for precise identification of species, although the collected specimen is very similar to Z. degenerata Borgmeier 1925.

This study was conducted in specific locations in the state and the total diversity of phorids for Rio Grande do Sul should be much higher. This is the first effort focused in understanding and recording the Phoridae fauna in the state and it may foster future studies on the taxonomy, ecology, and behavior of the group in the Neotropical region.

\section{Acknowledgements}

We thank Ândrio Zafalon da Silva, Msc., Dr Frederico Dutra Kirst and Roberta Marques, MSc, for their assistance in the collection process. Dr Edison Zefa is thanked for allowing the use of the photographic equipment. Thanks are also extended to Dr Carlos Einecker Lamas for permitting the comparison with the material in the MZUSP collection. Dr Danilo Ament provided valuable literature. We express our gratitude to $\mathrm{CNPq}$ for the financial support (process no. 473949/2010-5) and to CAPES for the Ph.D. scholarship awarded to JLPD. We would like to thank also Instituto Chico Mendes de Conservação da Biodiversidade and IBAMA for granting the collecting licenses. The constructive comments by 2 referees helped improve the manuscript; we thank them.

\section{Authors' Contributions}

JLPD identified the material and wrote the text, DBV sampled the material and helped sorting phorids, RFK collected the specimens and helped improving the manuscript.

\section{References}

Ament DC (2014) Taxonomic revision of the genus Chaetocnemistoptera Borgmeier (Diptera: Phoridae), with the description of five new species. Zootaxa 3753 (4): 301-322. https://doi.org/10.11646/ zootaxa.3753.4.1

Ament DC, Amorim DS (2016) Taxonomic revision of Coniceromyia Borgmeier(Diptera: Phoridae), with the description of three new species from Brazil. Zootaxa 4086 (1): 01-87. https://doi.org/10.11646/ zootaxa.4086.1.1

Ament DC, Brown BV (2016) Family Phoridae. Zootaxa 4122 (1): 414-451. https://doi.org/10.11646/zootaxa.4122.1.37

Ament DC, Pereira TPL (2017) Phoridae in Catálogo Taxonômico da Fauna do Brasil. PNUD. http://fauna.jbrj.gov.br/fauna/faunado brasil/183530. Accessed on: 2017-12-20.

Azevedo RR, Krüger RF (2013) The influence of temperature and humidity on abundance and richness of Calliphoridae (Diptera). Iheringia. Série Zoologia 103: 145-152. https://doi.org/10.1590/ S0073-47212013000200010

Borgmeier T (1924) Eine neue myrmecophile Phoridengatfung aus Brasilien (Dipt.). Entomologische Mitteilungen 13: 237-239.

Borgmeier T (1926) Phorídeos novos ou pouco conhecidos do Brasil. Boletim do Museu Nacional do Rio de Janeiro 2 (5): 39-52.

Borgmeier T (1928) Nota previa sobre alguns Phorídeos que parasitam formigas cortadeiras dos gêneros Atta e Acroyrmex. Boletim Biológico de São Paulo 14: 119-126.

Borgmeier T (1962) Versuch einer Uebersichtueber die neotropischen Megaselia-Arten, sowie neue oder wenig bekannte Phoriden verschiedener Gattungen (Diptera, Phoridae). Studia Entomologica 5: $289-488$.

Borgmeier T (1963) A new genus of phorid flies, with the description of seven new species (Diptera, Phoridae). Revista Brasileira de Entomologia 23 (2): 165-170.

Borgmeier T (1968) A catalogue of the Phoridae of the world. Studia Entomologica 11: 1-367.

Borgmeier T (1969a) New or little-known phorid flies, mainly of the Neotropical region. Studia Entomologica 12: 33-132.

Bormgeier T (1969b) Bredin-Archbold-Smithsonian Biological Survey of Dominica: the Phoridae of Dominica (Diptera). Smithsonian contributions to Zoology 23: 1-69.

Borgmeier T (1971) Further studies on phorid flies, mainly of the Neotropical region (Diptera, Phoridae). Studia Entomologica 14: $1-172$. 
Borgmeier T, Prado AP (1975) New or little-known phorid flies, with description of eight new genera (Diptera, Phoridae). Studia Entomologica 18: 3-90.

Brown BV (1987) Classification, reconstructed phylogeny and geographic history of the Neotropical phorid flies of the genus Gymnophora (Diptera: Phoridae). Journal of Natural History 21: $1477-1524$.

Brown BV (2004) Revision of the subgenus Udamochiras of Melaloncha beekilling flies (Diptera: Phoridae: Metopininae). Zoological Journal of the Linnean Society 140: 1-42.

Brown BV (2005) Revision of the Melaloncha (M.) furcata-group of bee-killing flies (Diptera: Phoridae). Insect Systematics and Evolution 36: 241-258.

Brown BV, Borkent A, Cumming JM, Wood DM, Woodly NE, Zumbado MA (2010) Phoridae (Hump-backed flies, scuttle flies), in: Brown BV et al. (Eds) Manual of Central America Diptera, vol. 2. NRC Research Press, Ottawa, 725-761.

Brown BV, Amorim DS, Kung GA (2015) New morphological characters for classifying Phoridae (Diptera) from the structure of the thorax. Zoological Journal of the Linnean Society 173: 424-485.

Brown BV, Kung GA (2007) Revision of the New World Dohrniphora Dahl species with hind tibial setae (Diptera: Phoridae). Arthropod Systematics \& Phylogeny 65: 157-237.

Brown BV, Kung GA (2010) Revision of the New World Dohrniphora Dahl species lacking large hind tibial setae (Diptera: Phoridae). Zootaxa 2699: 1-142.

Carvalho CJB, Rafael JA, Couri MS, Silva VC (2012) Diptera Linnaeus, 1758, in: Carvalho CJB et al. (Eds.) Insetos do Brasil: Diversidade e Taxonomia. Holos Editora, Ribeirão Preto, São Paulo, 701-743.

Disney RHL (1983) A useful new character in the giant genus Megaselia (Diptera: Phoridae) with two new species from Britain. Zeitschrift für Angewandte Zoologie 70: 225-234.

Disney RHL (1994) Scuttle Flies - the Phoridae. Chapman \& Hall, Publishers, London, 467 pp.

Disney RHL(2003) Seven new species of New World Pulliciphora Dahl (Diptera: Phoridae) with a key to the Neotropical species. Zootaxa 162: 1-22.

Disney RHL (2008) Review of Neotropical Chonocephalus Wandolleck (Diptera: Phoridae). Zootaxa 1772: 1-54.

Disney RHL, Bragança MAL (2000) Two new species of Phoridae (Diptera) associated with leaf-cutter ants (Hymenoptera: Formicidae). Sociobiology 36: 33-39.

Disney RHL, Elizalde L, Folgarait PJ(2006) New species and revision of Myrmosicarius (Diptera: Phoridae) that parasitize leaf-cutter ants (Hymenoptera: Formicidae). Sociobiology 47: 771-809.

Duarte JLP, Krüger RF, Carvalho CJB, Ribeiro PB (2010) Evidence of the influence of Malaise trap age on its efficiency in the collection of Muscidae (Insecta, Diptera). International Journal of Tropical Insect Science 30: 115-118.

Duarte JLP, Krüger RF (2015). First record and range extension of Ceriomydas crassipes (Westwood, 1841) (Insecta, Diptera, Mydidae) from Rio Grande do Sul, Brazil. Check List 11: 1700. https:// doi.org/10.15560/11.4.1700

Gaston KJ (1991) The magnitude of global insect species richness. Conservation Biology 5: 283-296.

Hash JM, Brown BV (2015) Revision of the New World species of the millipede-parasitic genus Myriophora Brown (Diptera: Phoridae). Zootaxa 4035: 1-79.

Hochmüller CJ, Lopes-da-Silva M, Valente VLS, Schmitz HJ (2010) The drosophilid fauna (Diptera, Drosophilidae) of the transition between the Pampa and Atlantic Forest Biomes in the state of Rio Grande do Sul, southern Brazil: first records. Papéis Avulsos de Zoologia 50: 285-295.

Kempf WW (1972) Dedication to Fr. Thomas Borgmeier, O.F.M., Sc.D. on his 80th birthday, October 31, 1972. Studia Entomologica 15: 1-2.

Kirst FD, Marinone L, Krüger RF (2015) New distribution records for Sciomyzidae species (Insecta, Diptera) from Rio Grande do Sul, Brazil. Check List 11: 1552. https://doi.org/10.15560/11.1.1552

Krüger RF, Krolow TK (2015) Seasonal patterns of horsefly richness and abundance in the Pampa biome of southern Brazil. Journal of Vector Ecology 40: 364-372.

Krüger RF, Carvalho CJB, Ribeiro PB (2010) Assembly rules in muscid fly assemblages in the grasslands biome of southern Brazil. Neotropical Entomology 39: 345-353.

Uribe S, Brown BV, Bragança MAL, Queiroz JM, Nogueira CA (2014) New species of Eibesfeldtphora Disney (Diptera: Phoridae) and a new key to the genus. Zootaxa 3814: 443-450.

Valer FB, Neutzling AS, Garcia FRM, Gottschalk MS, Blauth ML (2013) The first record of Zygothrica orbitalis (Sturtevant, 1916) for the state of Rio Grande do Sul and the southernmost limits for seven species of Drosophilidae (Insecta: Diptera). Drosophila Information Service 96: 120-123.

Vianna ÉES, Brum JG, Ribeiro PB, Berne MEA, Silveira JRP (1998) Synanthropy of Calliphoridae (Diptera) in Pelotas, Rio Grande do Sul state, Brazil. Revista Brasileira de Parasitologia Veterinária 7: 141-147. 